\title{
The impact of R\&D intensity on corporate reputation: Interaction effect of innovation with high social benefit
}

\author{
Robert Carlton Padgett ${ }^{1}$, Rosamaria Cox Moura-Leite ${ }^{2}$ \\ ${ }^{1}$ University of Salamancy (Spain), ${ }^{2}$ Mato Grosso do Sul Federal University (Brazil) \\ rcpcooper@gmail.com, rosamariamouraleite@gmail.com
}

Received March, 2012

Accepted June, 2012

\section{Abstract}

Purpose: This article analyzes the effect that Research and Development (R\&D) intensity has on corporate reputation, and how this effect can be positively moderated when innovation yields some kind of social benefits.

Design/methodology/approach: As a theoretical framework we use the resource based view theory and the institutional theory. For the empirical analysis we used the panel data technique to estimate our models, the sample is composed of 257 US firms and covers a four-year period from 2004 to 2007.

Findings: The results of this research demonstrates that R\&D with the moderation of innovation with high social benefits will produce a greater positive effect on corporate reputation than R\&D by itself, since R\&D activities can produce innovations that do not produce any social benefit which may not be perceived by stakeholders.

Practical implications: Innovative firms should focus their efforts on identifying opportunities in their R\&D processes to initiate related corporate social responsibility activities that could help them build a good reputation, which in the long run can give them a competitive advantage and profitable results. 
Originality/value: Recently several studies have demonstrated that $R \& D$ is related with corporate social responsibility and that it is important to include both variables when studying financial performance. Our research is novel in the sense that we are applying the same logic but studying the relationship with corporate reputation, which has been scarcely talked about in existing literature.

Keywords: corporate reputation, corporate social responsibility, innovation with high social benefit, resource based view theory, institutional theory.

Jel Codes: M14

\section{Introduction}

Most successful companies like to position themselves and be identified as highly innovative and to be social responsible. Research seems to increasingly concur that CSR and R\&D are complementary (Branco \& Rodrigues, 2006; McWilliams \& Siegel, 2000; Padgett \& Galan, 2010) and that both influence positively the company's overall reputation (Chun, 2006). Although, little is known about how the link between social responsibility and R\&D impacts on corporate reputation.

This article analyzes the effect that R\&D Intensity, which has long been associated with the innovative capacities of firms (Anagnostopoulou \& Levis, 2008), has on corporate reputation (CR), and how this effect can be positively moderated when innovation produces positive social actions. To support our analysis we will make use of the resource based view (RBV) and institutional theories. The RBV theory, recognizes the importance of intangible resources, making it ideal to study such variables as corporate reputation and research and development (R\&D), since they are difficult to imitate and substitute and lead to competitive advantages (Branco \& Rodrigues, 2006). According to Oliver (1997), in order to complement the RBV theory and analyze the social context of resources, it is necessary to include the institutional theory (DiMaggio \& Powell, 1991; Scott, 1995), which examines the role of social influences and pressures for social conformity in determining organizations' decisions and actions. The RBV and the institutional theories provide substantial support to the study of intangible resources plus add importance of how stakeholder pressures influence firms' decisions, which allows us to demonstrate the importance of R\&D, social benefits obtained from this R\&D activities and how 
these actions are perceived by stakeholders, creating a good reputation for firms that incur in it.

Our research is based on the idea that $R \& D$ activities that produce social benefits will obtain a greater positive effect on $C R$ than $R \& D$ by itself, since R\&D activities can produce innovations that do not produce any social benefit and thus, may not be perceived by stakeholders, which will result in a lower impact on the firm's reputation. On the other hand when innovation that produce social benefits are in the picture, stakeholders will perceive this effect and thus have a greater positive effect on the firm's CR.

Existing literatures, rarely link firm's social activities and innovation as key elements for a sustainable reputation, but there is one research by Chun (2006), which has studied the effect that R\&D has on reputation. The research found that in order for firms to be innovative and have a good reputation, they need to be socially responsible. Even though this research studied the same effect that we are analyzing in this research, we provide a different focus since we include other variables such as innovation with high social benefit contributing to the literature in several different ways: first, we are studying the interaction between three variables that until now have not been studied in this way; second, our research gives insights to managers that if they want to improve their reputation with R\&D activities, they might not achieve the desired results, since R\&D alone may not have a positive influence on $C R$, but when a firm's R\&D produces some kind of social benefit, then the firms' reputation will be positively affected; third, our research adopted a panel data methodology, a technique that allows us to control the risk of unobserved heterogeneity on the manager's conceptions of social responsibility and company strategy (Bouquet \& Deutsch, 2008).

The remainder of the paper is organized as follows: the second section reviews the RBV and institutional theory, the empirical evidence, and the hypothesis is presented; the third section describes the data and estimation method used in our analysis; the results are discussed in our fourth section and, finally, the fifth and last section presents our conclusions to this research.

\section{Theory and hypothesis}

\section{Resource based view and institutional theory}

This article analyzes the impact that R\&D Intensity has on $C R$, and how this effect is positively moderated by innovations with high social benefits. As a theoretical 
framework for this analysis we will make use of the RBV and institutional theories. The resource-based view (RBV) theory of strategic management (Barney, 1991; Peteraf, 1993; Wernerfelt, 1984) examines resources and capabilities of firms, which enables them to obtain a competitive advantage and above average rates of return. According to the RBV, firms with assets that are valuable and rare possess a competitive advantage and may expect to earn superior returns, and those firms whose assets are also difficult to replicate may have a sustained superior financial performance (Barney, 1991; Grant, 1991; Roberts \& Dowling, 2002). The RBV theory, recognizes the importance of intangible resources, making it ideal to study such variables as research and development (R\&D), corporate social responsibility (CSR) and CR since they are difficult to imitate and substitute and lead to competitive advantages (Branco \& Rodrigues, 2006). The RBV is not only about internal competencies and how they can generate competitive advantages, since the firm is also affected by external factors, and "resources cannot be evaluated in isolation. "A resource that is valuable in a particular industry or at a particular time might fail to have the same value in a different industry or chronological context" (Collis \& Montgomery, 1995: page 120). According to Oliver (1997), in order to complement the RBV theory and analyze the social context of resources, it is necessary to include the institutional theory (DiMaggio \& Powell, 1991; Scott, 1995), which examines the role of social influences and pressures for social conformity in determining organizations' decisions and actions. Furthermore the institutional theory predicts that firms adopt specific business behaviors to achieve access to resources and support of critical stakeholders (DiMaggio \& Powell, 1983; Oliver, 1991; Scott, 1995; Tolbert \& Zucker, 1983).

Within an institutional perspective, firms operate within a social framework of norms, values, and assumptions about appropriate or acceptable economic behavior (Oliver, 1997). The institutional view suggests that the motives of human behavior extend beyond economic optimization to social justification and social obligation (Zukin \& DiMaggio, 1990). According to institutional theorists, conformity to social expectations contributes to organizational success and survival (Baum \& Oliver, 1991; Carroll \& Hannan, 1989; DiMaggio \& Powell, 1983; Oliver 1991). Scott (1987: page 498) adds to this statement when he observes that organizations "conform because they are rewarded for doing so through increased legitimacy, resources, and survival capabilities".

The main argument of institutional theory, is that "firms tendencies towards conformity with predominant norms, traditions, and social influences in their internal and external environments lead to homogeneity among firms in their 
structures and activities, and that successful firms are those that gain support and legitimacy by conforming to social pressures" (Oliver, 1997: page 700). Legitimate organizations meet and conform to societal expectations and as a result are accepted, valued, and taken for granted as right fitting, and good (Aldrich \& Fiol, 1994; Meyer \& Scott, 1983) and therefore, legitimacy results in attainment of a particular reputation (Doh, Howton, Howton \& Siegel, 2009).

\section{Corporate reputation and research \& development}

Roberts and Dowling (2002) conceptualize reputation as a perceptual representation of a company's past actions and future prospects-describing the firm's overall appeal to key constituents compared with leading rivals. Organizational researchers, following the lead of economists, analyze issues of social identity under the rubric of reputation (Weigelt \& Camerer, 1988) and depict it as a critical antecedent of organizational performance (Itami, 1987; Fombrun \& Shanley, 1990; Hall, 1993). Reputation and legitimacy need not be viewed as competing specifications of organizational identity but are rather complementary aspects of creating an organizational identity (Rao, 1994). If reputation is based on signals and legitimacy flows from symbols, both signals and symbols are needed to create impressions on audiences (Goffman, 1969; Feldman \& March, 1981). Fombrun and Shanley (1990: page 233) mention that having a favorable reputation may lead to favorable consequences, such as the charging of premium prices to the customer, the attraction of better applicants and more investors.

Reputation has been identified as one of the most important intangible resources that provide a firm sustainable competitive advantage. In the resource-based view, resources are classified as tangible, intangible, and personnel-based (Grant, 1991). Tangible resources include financial reserves and physical resources such as plant, equipment, and stocks of raw materials. Intangible resources include reputation, technology, and human resources; the latter include culture, the training and expertise of employees, and their commitment and loyalty. Roberts and Dowling (2002, page 1091) argue that "the development of a good reputation takes considerable time, and depends on a firm making stable and consistent investments over time." However, as with any valuable resource, it is the difficulty to create, trade, or imitate that explains the strategic value it has for the firm.

Fombrun and Shanley (1990) view corporate reputation as the result from a process in which firms compete for social status in a market characterized by incomplete information. However, a firm's reputation is determined not only by the signals received directly from the firm but also from other sources, such as the 
media, stock market and stakeholders. A firm's stakeholders are assumed to respond to market and accounting signals representing corporate performance, institutional signals about its visibility and socially responsibility, and strategy signals related to corporate postures such as differentiation and diversification. As Roberts and Dowling (2002, page 1078) point out, CR "reflects the extent to which external stakeholders see the firm as "good" and not "bad"'". Some scholars (Surroca, Tribó \& Waddock, 2009; Orlitzky, Schmidt \& Rynes, 2003; Wood, 2010) maintain that the "reputational effects" of engaging in social practices provide the crucial link between social initiative and profitability and according to QuevedoPuente, Fuente-Sabaté \& Delgado-García (2007), there is no controversy that corporate social performance influences firm's reputation.

Other studies have focused on the relationship between firm performance and CR. According to Godfrey (2005), CR in and of itself has no cash value, but it may generate economic value. In an empirical research, Roberts and Dowling (2002) demonstrated that firms with strong positive reputations possess a cost advantage because, ceteris paribus, employees prefer to work for high-reputation firms. At the same time, suppliers are less concerned about contractual hazards when transacting with high-reputation firms, good reputations should also lead to lower contracting and monitoring costs (Dyer \& Chu, 2003). Moreover, high-reputation firms are perceived as providing more value, what often allows them to charge a higher price for their products, and their customers are more loyal (Keh \& Xie, 2008). Under a financial perspective, the market beliefs that such companies deliver sustained earnings and future growth. Consequently, they enjoy higher price-earnings and market values, and lower costs of capital (Carter \& Ruefli, 2006; Fombrun, 1996; Fombrun \& Shanley, 1990; Roberts \& Dowling, 2002).

As well as corporate reputation, it has been long argued that investment in R\&D leads to improvements in long-run economic performance (Griliches, 1979). These results are robust to different time periods and levels of aggregation. For example, using data from over 2000 firms, Lichtenberg and Siegel (1991) report a strong positive correlation between $R \& D$ investment and growth in total factor productivity. Clark and Griliches (1984) find similar results at the line-of-business level. Several researches report similar positive associations between R\&D, accounting profits, and long-term shareholder returns and other proxies for longterm financial performance, such as Ben-Zion (1984), who studied the relationship between R\&D and firm's market value, Guerard, Bean, and Andrews (1987), who analyzed the interdependencies of the research and development, investment, dividend, and new debt financing decision, Guerard, Stone, and Andrews (1988), 
who studied R\&D expenditures in an international economy, Griliches (1998), who studied R\&D and productivity and Hall (1999), who studies innovation and market value.

Branco and Rodrigues (2006) state that innovations that can improve product quality is related with $\mathrm{CR}$, because consumers perceive this product quality improvement. This statement is reinforced by Russo and Fouts (1997) research, which suggests that reputation effects and the ability to influence public policy by R\&D activities for compliance standards enhances the competitive advantage of environmentally proactive firms. This study also demonstrates that firms that assume a proactive environmental policy often redesign and improve processes and physical resources, through R\&D activities to enhance methods for waste reduction and operational efficiency.

Another research by Galaskiewicz's (1991) has stated that firms tend to act socially responsible when normative or cultural institutions create incentives for such behavior. The institutional theory supports the intentions of firms to participate in R\&D activities because they attend to stakeholder pressures that call for innovation, and thus creating a good reputation (Quevedo-Puente et al., 2007). Organizational culture that emphasizes innovation will engender positive responses by employees. While the relationship between innovation and integrity could be a virtuous circle in which innovation in a company's social and business practices strengthens its reputation and the self-respect of its employees (Schwartz \& Gibb, 1999), the competitive environment demands innovation and aggressiveness for global competitiveness and survival. Reputation of a company is shaped through developing virtuous character; innovativeness is the business virtue which leads to customer and employee satisfaction. (Chun, 2006)

Based on the above arguments, we therefore suggest the following hypothesis:

Hypothesis 1: R\&D intensity positively affects corporate reputation.

\section{Innovation with high social benefit}

A recent research by Wagner (2010) analyzes the link between innovation with high social benefits and corporate social performance. The author describes how firms can do innovation that produces private benefits, such as improved products, creating advantages to the firm. Also, these innovations can produce social benefits, such as process improvements that reduce pollution. The author establishes that innovation should have equilibrium, where companies are 
encouraged to innovate because they will obtain higher rents and at the same time give something to society. According to Wagner (2010), innovation with high social benefits can be defined as an innovation that has a positive direct social effect, such as reduced environmental externalities and provision of products or services for the economically disadvantaged.

Several researchers have found a link between innovation and CSR. For example, McWilliams and Siegel (2000) demonstrate, innovation is a significant driver of firm performance, and when innovation is included among the independent variables the significance of the CSR-financial performance relationship disappears. Also, they prove that CSR is positively correlated with R\&D intensity. Another research by Hull and Rothenberg (2008), corroborate this finding and finally Padgett and Galan (2010) study the relationship between these two variables and found a significant positive effect. Fombrun and Shanley (1990) established that investing in CSR attributes and activities may be important elements of product differentiation and reputation building. McWilliams, Siegel and Wright (2006) expands this statement by giving the example where consumers prefer products with a CSR characteristic, because they believe it is better than the product without such a characteristic. For example, a "hybrid" version of a Honda Accord generates less pollution than a standard Honda Accord. In this example, it is clear to most consumers that the hybrid car is better than the standard model. McWilliams et al. (2006) state that vertical differentiation occurs when most consumers prefer one product over another and this type of differentiation can strengthen or maintain the reputation of the firm which adds value in addition to allowing the firm to meet a particular market demand (Fombrun \& Shanley, 1990).

McWilliams et al. (2006) state that CSR can be an integral element of a firm's business and corporate-level differentiation strategies and therefore, it should be considered as a form of strategic investment, since CSR can be viewed as a form of reputation building. It is clear that such companies are likely to derive greater benefits from the use of CSR related innovation for reputation enhancement and/or protection. Other researchers, state that companies incur in social innovative actions because they obtain benefits in return, such as Scott's (1987) work where it is observed that organizations "play the game" because they are rewarded for doing so through increased legitimacy, resources and survival capabilities. Firms should see that by innovating with high social benefits firms create differentiation and legitimacy. The basic argument of the RBV theory is that rare, specialized, inimitable resources cause firm heterogeneity, and that successful firms are those that acquire and maintain valuable idiosyncratic resources for sustainable 
competitive advantage. If firms go one step further and conform to predominant norms, traditions, and social influences in their internal and external environments will gain support and legitimacy, according to the institutional theory (Oliver, 1997) and become successful at least over the long term (Jones, 1995). In addition, firm's legitimacy, leads to obtaining a good reputation (Doh, Howton, Howton \& Siegel, 2009).

Furthermore there is a mutual dependence between corporations and society which implies that both business decisions and social actions must follow the principle of shared value. Choices must benefit both sides, because if either businesses or society pursue actions that benefit their own interests at the expense of the other, they will find themselves on a risky path, where a momentary gain of one will weaken the long-term prosperity of both (Porter \& Kramer, 2006). In interviews with senior managers in 14 successful European and American commercial organizations, Davies and Miles (1998) found that most firms promote core values as central to managing their reputation, and that these core values include reliability, caring, innovation, trust, social responsibility, honesty, integrity and fun. Additionally, they found that one of the cornerstones of reputation management is the social responsibility in the organizational culture of the firm. Existing literature rarely link CSR and innovation as key elements for a sustainable reputation even though these two elements influence CR as the statements above have implied.

Based on these insights, the following hypothesis can be stated:

Hypothesis 2: Innovation with high social benefit positively moderates the effect that $R \& D$ intensity has on corporate reputation.

\section{Methods}

\section{Sample and data}

The data was obtained from three sources: Thomson Reuters Datastream database, Kinder Lydenburg Domini (KLD) social rating data, and Fortune magazine's 'World's Most Admired Companies' survey data. It is made up of all those firms for data could be obtained. The final sample is composed of 257 US firms is unbalanced and covers a four-year period from 2004 to 2007.

KLD database is a reliable source for CSR measures and has been widely used by previous researchers (Orlitzky et al., 2003; Margolis, Elfenbein \& Walsh, 2007; Wood, 2010). It comprises numerical assessments on thirteen categories. Seven of 
those relate to social responsibility qualitative issues' areas and the remaining six to engagement in controversial business. For the first set of dimensions, there is a subset of items regarded as strengths and concerns. The qualitative issues are: product issues; community relations; environmental issues; human rights; governance; employees' relations and diversity of the work force. The rating is a binary system, where 1 indicates the presence of this item and 0 its absence. Previous researchers have tailored this rating system for their own objectives. From this database we extracted the CSR measure and also innovation with high social impact proxy, we give more detail about these measures later.

Fortune magazine's "World's Most Admired Companies" survey, our data to measure $C R$, is based on responses from executives, directors, and financial analysts and determines a reputation score from eight attributes ranked on 11point scales from poor to excellent. In order to maintain data consistency, respondents rate firms from their own sectors, thereby assuring an informative perceptual result. These attributes are long-term investment value; financial soundness; wise use of corporate assets; community and environmental friendliness; quality of management; product quality; innovativeness; and ability to attract, develop, and keep talented people. Fortune's ratings remain the most widely used reputation construct in empirical research (Sabate \& Puente, 2003); moreover, Fortune's data have the virtue of not being highly correlated with Kinder Lydenburg Domini (KLD) social rating data (Szwajkowski \& Figlewicz, 1999).

\section{Measures}

To measure $C R$, our dependent variable, we have used Fortune magazine's data survey. This is published annually in a March issue, and then we relate the reputation score of the current year with the data of precedent year. Due to the possible effect of past financial performance on reputation, the so-called halo effect, we regressed reputation on increasingly higher-order lags of return on asset (ROA) until no further significant improvement in R2 was observed (Roberts \& Dowling, 2002). We found no significant increases in R2 beyond three lags. Hence the R2 was only 0.018 , we adopt the reputation measure as the residual of reputation measure has a very similar behavior and decrease our dataset disabling our analyses. We adopt ROA as financial performance control variable as previous studies (e.g. Brammer \& Pavelin, 2006; Turban \& Greening, 1997). In addition, assuming the long-term effect of firms social issues on CR (Roberts \& Dowling, 2002), we have estimated the model with a two-year lag on the CR variable. 
To measure innovation with high social benefits we follow Wagner (2010) and construct a proxy for it using three useful variables of the KLD database, those that are related with firms' innovation. The first variable is taken from by the strength environment issue qualitative area, called ENV-str-A by KLD, and this variable indicates that a firm has newly introduced products or services which protect the environment or is achieving significant sales with such innovative products or services because of its concern with protecting the environment. The second and third are taken from by the strength product issue qualitative area, the KLD database respectively names them as PRO-str-X and PRO-str-C. PRO-str-X measure whether a firm's products have notable social benefits that are highly unusual or unique for its industry and PRO-str-C records whether part of a firm's mission is the provision of products or services for the economically disadvantaged. These three variables are binary and assume value 1 if the firms have this characteristic and 0 when they do not. Our variable innovation with high social benefits is the sum of these three variables.

To measure R\&D intensity, we use a proxy of R\&D, calculated by dividing total expenditure in R\&D by total number of employees. This ratio is "less sensitive to the spurious effects of business cycles, accounting manipulations, and asset sales than R\&D spending as a proportion of sales" (Baysinger, Kosnik \& Turk, 1991: page 207), and is positively related to patents and product innovations (Hitt, Hoskisson \& Kim, 1997).

We have used control variables based on the degree to which they may influence the effect that innovation with high social benefit and R\&D intensity have on CR. We have used company size because previous articles have suggested it is closely related to CR (e.g. Brammer \& Pavelin, 2004), and we measure it as the total assets defined on a log scale. Risk is another factor used as a control variable in CR models. In line with Brammer and Pavelin (2006), we expect a negative relation between risk and reputation, as high business risk impacts negatively on CR (Fombrun \& Shanley, 1990). Risk is measured as the ratio of total debt to total assets.

Therefore, for the purpose of this research it is also necessary to control the firms' overall social responsibility index. We used the five KLD dimensions consistently reported between 1996 and 2007: product issues; community relations; environmental issues; employees' relations and diversity of the work force. These dimensions have been selected because they reflect corporate attention to primary stakeholders with an impact on a firm's survival (Clarkson, 1995) and exert 
considerable influence on corporate strategy (Berman, Wicks, Kotha \& Jones, 1999). We develop the same scale used by Hillman and Keim (2001), which is also used by other authors (e.g. Hull \& Rothenberg, 2008). All of the strengths of each dimension are rated on a scale ranging from 0 to +2 , in the same way all concerns of each dimension are rated from -2 to 0 . Then, we add the strengths scale plus the concerns scale of each dimension, having as a result a scale ranging from -2 to +2 . We build the corporate social responsibility measure giving equal weights to the five dimensions cited above. (Hillman \& Keim, 2001)

In addition to these variables, a control needs to be made of the controversial business involvement (CBI) impact. According to Dowling (2004) the CBI by firms may have a negative effect on their reputation. In order to measure it, we focus on the KLD dimension concerning firm operations related to alcohol, tobacco, gambling, firearms, nuclear power and military contracting. These CBI ratings differ from the corporate social performance ones described earlier, as they are rated as 'concerns' only. For each concern, we give 0 to indicate its avoidance and 1 to indicate involvement. We have given equal importance to the categories adopted from KLD to construct this measure.

Finally, it may be that, even controlling for financial performance and all the other firm attributes we have discussed, reputation varies systematically across sectors (Brammer \& Pavelin, 2004, 2006; Dowling, 2004). Some business activities may predispose a firm to a better reputation than other activities. To avoid this bias, we have used dummy variables based on the DataStream industry classification. Accordingly, we allocated each firm to one of twelve sectors: basic industries, cyclical consumer goods, cyclical services, general industries, information technology, non-cyclical goods, non-cyclical services, resource, financial and utilities.

\section{Results}

We used the panel data technique to estimate our models. Unlike cross-sectional analysis, panel data analysis allows us to control every firm and has its own specificity that gives rise to a particular behaviour closely linked to the company's strategy. Unobserved variables can be eliminated by specifying a fixed-effects or a random-effects model, as several sequential (yearly) observations of the same company are recorded.

We carried out a Hausman test that indicated correlation between individual effects and independent variables. In the light of this, the fixed effect is best suited than 
the between effects. As well as the individual effects added to control for the crossreference units, we have also included time dummies in our model. With these temporal effects we reduce a source of bias by capturing the events that all states were subjected to in a given year. An $\mathrm{F}$ test of significance was performed to assert the joint significance of the temporal dummies and the result was that they contribute to the model overall's significance. We have also applied the Wooldridge and Modified Wald tests to examine potential autocorrelation in our panel and heteroskedasticity problems in our fixed effect equation. In all cases the results were positive. Consistent with Beck and Katz (1995), we have corrected both problems using panel corrected standard errors through a Prais-Winsten regression.

\begin{tabular}{|c|c|c|c|c|c|c|c|c|c|c|}
\hline & Variable & Mean & s.d. & & & & & & & \\
\hline 1 & $\mathrm{CR}$ & 6.35 & 1.04 & 1 & & & & & & \\
\hline 2 & $\begin{array}{c}\text { Innovation with } \\
\text { high social } \\
\text { benefit }\end{array}$ & 0.12 & 0.33 & $0.10 *$ & 2 & & & & & \\
\hline 3 & R\&D intensity & 0.04 & 0.06 & -0.03 & 0.03 & 3 & & & & \\
\hline 4 & $\begin{array}{l}\text { Corporate social } \\
\text { responsibility }\end{array}$ & 0.40 & 0.76 & $0.16 *$ & $0.24 *$ & $0.37 *$ & 4 & & & \\
\hline 5 & $\mathrm{CBI}$ & 0.20 & 0.44 & 0.02 & 0.09 & -0.08 & -0.05 & 5 & & \\
\hline 6 & Tobin & 1.78 & 1.02 & $0.24 *$ & -0.01 & $-0.34 *$ & $0.28 *$ & $-0.12 *$ & 6 & \\
\hline 7 & Risk & 0.22 & 0.15 & -0.05 & 0.04 & $-0.21 *$ & -0.05 & $0.13^{*}$ & $-0.30 *$ & 7 \\
\hline 8 & Size & 16.09 & 1.29 & $0.34 *$ & $0.12 *$ & $0.14 *$ & $0.14 *$ & $0.14 *$ & -0.07 & $0.14 *$ \\
\hline
\end{tabular}

Table 1. Descriptive statistics and Correlations matrix ${ }^{a}$

Table 1 provides descriptive statistics and correlation matrices for the variables. To test for multicollinearity, we checked the correlation matrix and variance inflation factors (VIFs) of the regression models on both pooled data and individual years of the data. We found that all VIFs were lower than 3. Table 1 show that corporate reputation (CR) has a positive significant correlation with innovation with high social benefits and CSR. As predicted by the literature, these results support the positively association between firms social issues and CR. We can also see that R\&D intensity and CBI have no significant correlation with CR.

Table 2 presents the results of the regression analyses. Our first model shows the effect that the control variables have on our dependent variable, CR and has an Rsquared of 0.6467 . We controlled for controversial business involvement (CBI), financial performance, R\&D, firm risk, firm size, advertising intensity and sector. The results show that $\mathrm{CBI}$ is not significantly associated with in all of our. Firm size is significantly and positively associated with CR $(p<0.01)$ in all models, consistent with Brammer and Pavelin (2004). Furthermore, there is a significant effect of Tobin's q, risk and size on CR in all of our models, like prior studies have supported these significant relationships. 


\begin{tabular}{|c|c|c|c|c|}
\hline Variables & Model 01 & Model 02 & Model 03 & Model 04 \\
\hline \multicolumn{4}{|c|}{ Innovation with high social benefit $* R \& D$ intensity } & $\begin{array}{c}3.7876^{*} \\
(2.2781)\end{array}$ \\
\hline \multicolumn{3}{|c|}{ Innovation with high social benefit } & $\begin{array}{r}0.1376 \\
(0.0993) \\
\end{array}$ & $\begin{array}{r}-0.0349 \\
(0.1255) \\
\end{array}$ \\
\hline \multicolumn{2}{|l|}{$R \& D$ intensity } & $\begin{array}{c}-1.6328^{*} \\
(0.8938)\end{array}$ & $\begin{array}{r}-1.6367^{*} \\
(0.8860)\end{array}$ & $\begin{array}{r}-1.8571^{*} \\
(0.8896) \\
\end{array}$ \\
\hline $\begin{array}{c}\text { Corporate } \\
\text { social } \\
\text { responsibility }\end{array}$ & $\begin{array}{r}0.1124^{*} \\
(0.0556)\end{array}$ & $\begin{array}{r}0.1210 * \\
(0.0554)\end{array}$ & $\begin{array}{r}0.1060 * \\
(0.0584)\end{array}$ & $\begin{array}{r}0.1075 * \\
(0.0582)\end{array}$ \\
\hline CBI & $\begin{array}{r}0.0580 \\
(0.0909)\end{array}$ & $\begin{array}{r}-0.0447 \\
(0.0898)\end{array}$ & $\begin{array}{r}0.0483 \\
(0.0889)\end{array}$ & $\begin{array}{r}0.0412 \\
(0.0902)\end{array}$ \\
\hline Tobin & $\begin{array}{r}0.2687 * * * \\
(0.0397) \\
\end{array}$ & $\begin{array}{r}0.2801 * * * \\
(0.0403) \\
\end{array}$ & $\begin{array}{r}0.2830 * * * \\
(0.0401) \\
\end{array}$ & $\begin{array}{r}0.2851^{* * *} \\
(0.0403)\end{array}$ \\
\hline Risk & $\begin{array}{r}-0.4387 * * * \\
(0.0773) \\
\end{array}$ & $\begin{array}{r}-0.4365 * * * \\
(0.0774) \\
\end{array}$ & $\begin{array}{r}-0.4336 * * * \\
(0.0768) \\
\end{array}$ & $\begin{array}{r}-0.4382 * * * \\
(0.0767)\end{array}$ \\
\hline Size & $\begin{array}{r}0.3109 * * * \\
(0.0363) \\
\end{array}$ & $\begin{array}{r}0.3201 * * * \\
(0.0362) \\
\end{array}$ & $\begin{array}{r}0.3191 * * * \\
(0.0359) \\
\end{array}$ & $\begin{array}{r}0.3199 * * * \\
(0.0360) \\
\end{array}$ \\
\hline -cons & $\begin{array}{r}1.2270 * \\
(0.7162) \\
\end{array}$ & $\begin{array}{r}1.0698 \\
(0.7141) \\
\end{array}$ & $\begin{array}{r}1.0661 \\
(0.7091) \\
\end{array}$ & $\begin{array}{r}1.0636 \\
(0.7098) \\
\end{array}$ \\
\hline $\mathrm{R} 2$ & 0.6467 & 0.6461 & 0.6365 & 0.6395 \\
\hline Wald chi2 & (16) 260.33 & (17) 270.48 & (18) 280.03 & (19) 282.96 \\
\hline
\end{tabular}

Estimation also includes dummy for the years (2005 - 2007) and for industry.

Standard errors in parentheses under the coefficients.

$\mathrm{n}=703 . * \mathrm{p} \leq 0.10 ; * * \mathrm{p} \leq 0.05 ; * * * \mathrm{p} \leq 0.01$

Table 2. Results of regression analyses corporate reputation - dependent variable

Our second model, shows the effect that R\&D intensity has on $C R$, it has an Rsquared of 0.6461 and the results demonstrated that R\&D intensity affects CR negatively at a $p<0.10$, although we expected an opposite result, thus giving proof to reject our first hypothesis. Our third model has an R-squared of 0.6395 , and shows that innovation with high social benefit does not have a significant effect on CR. Finally our fourth model, studies how innovation with high social benefit moderates the effect that R\&D intensity has on $C R$. Our fourth model has an Rsquared of 0.6395 , and as can be seen, the moderating effect that Innovation with high social benefit has on the impact that $R \& D$ intensity has on corporate reputation is significant and positive at a $p<0.10$, which provides support for Hypothesis 2. Our third and fourth models display that there is no significance in the effect that innovation with high social benefits has over CR.

\section{Discussion and conclusion}

The resource based view and the institutional theories allowed us to analyze the effect that R\&D intensity has on $C R$, and how this effect is positively moderated by innovations with high social benefits. The RBV theory, recognizes the importance of intangible resources, making it ideal to study such variables as research and development (R\&D), corporate social responsibility (CSR) and corporate reputation (CR) since they are difficult to imitate and substitute and lead to competitive 
advantages (Branco \& Rodrigues, 2006). Even though the RBV is a prime example of a theory that integrates a management perspective with an economics perspective (Peteraf \& Barney, 2003), Oliver (1997) states that in order to complement the RBV theory and analyze the social context of resources, it is necessary to include the institutional theory. The combination of both the RBV and the institutional theories provide substantial support to the study of intangible resources plus add importance to stakeholder pressures, and how they influence firms' decisions. Both theories have allowed us to demonstrate the importance of $R \& D$, the social benefits obtained from $R \& D$ activities and how these actions are perceived by stakeholders, which might create a good reputation for firms that incur in R\&D activities.

The results of this research demonstrates that R\&D intensity has a negative effect on $\mathrm{CR}$, which provides support to reject our first hypothesis, which states that there is a positive effect between these two variables, giving us the conclusion that not every type of innovation can improve or have a positive influence on CR. Further research might be needed to determine which kinds of innovations can have a positive impact on CR. What is clear is that if R\&D's outcomes produce some kind of social benefit, then the impact that it has on $C R$ will be positive, as our results demonstrated. Innovation with high social benefit moderates in a positive way the effect that R\&D intensity has on $C R$, thus supporting our second hypothesis. R\&D with the moderation of innovation with high social benefits will produce a greater positive effect on $C R$ than $R \& D$ by itself, since $R \& D$ activities can produce innovations that do not produce any social benefit which may not be perceived by stakeholders. Because of this reason, R\&D by itself may have a lower impact on the firm's reputation. On the other hand when innovation with social benefit is in the equation, stakeholders will perceive this effect and thus have a greater positive effect on the firm's CR.

Existing literatures, rarely link firms' social activities and innovation as key elements for a good reputation, and through this research we have found that the interaction between a firm's social activities and innovation is needed to obtain a good reputation. Recently several studies have seen that R\&D is related with CSR and that it is important to include both variables when studying financial performance. Our research is novel in the sense that we are applying the same logic but studying the relationship with $C R$, which has been scarcely talked about in existing literature. In this way, our research is trying to fill this gap in literature, by providing evidence that innovations that produce social benefit moderate the effect that R\&D has on CR. Our research contributes to the literature in other different 
ways: first, we are studying the interaction between three variables (R\&D intensity, Innovations with high social benefit and $C R$ ) that until now have not been studied in this way, giving insight to the effect that R\&D has on CR when moderated by innovations with high social benefit. Second, our research adopted a panel data technique, which allows us to control the risk of unobserved heterogeneity on the manager's conceptions of social responsibility and company strategy (Bouquet \& Deutsch, 2008).

The managerial value of our research, gives insights to firms that are seeking to improve their reputation through R\&D activities, letting them know that they might not achieve the desired results, since R\&D alone may not have a positive influence on corporate reputation, but when a firm's R\&D produces some kind of innovation with social benefit, then the firms' reputation will be positively affected. Innovative firms should focus their efforts on identifying opportunities in their R\&D processes to initiate related CSR activities that could help them build a good reputation, which in the long run can give them a competitive advantage and profitable results. In addition, to having a synergy between CSR and innovation strategies, firms should make an effort to ensure that they "are a part of a larger society with a wider responsibility reaching beyond the narrow perspective of profit" (Quazi \& O'Brien, 2000), which is an opportunity for building a sustainable relationship with stakeholders (Polonsky, Suchard \& Scott, 1997; Quazi \& O'Brien, 2000).

For future researches it might be interesting to determine which types of R\&D activities produce a positive effect on $\mathrm{CR}$ and what other variables could moderate this relationship. Also, it would be interesting to study the context where the firms are located, such as the type of industry they are in.

\section{References}

ALDRICH, H.E.; FIOL, C.M. (1994). Fools rush in? The institutional context of industry creation. Academy of Management Review, 19: 645-670.

ANAGNOSTOPOULOU, S.C.; LEVIS, M. (2008). R\&D and performance persistence: Evidence from the United Kingdom. The International Journal of Accounting, 43: 293-320. http://dx.doi.org/10.1016/j.intacc.2008.06.004

BARNEY, J. (1991). Firm resources and sustained competitive advantage. Journal of Management, 17: 99-120. http://dx.doi.org/10.1177/014920639101700108 
BAUM, J.A.C.; OLIVER, C. (1991). Institutional linkages and organizational mortality. Administrative Science Quarterly, 36: 187-218. http://dx.doi.org/10.2307/2393353

BAYSINGER, B.D.; KOSNIK, R.D.; TURK, T.A. (1991). Effects of board and ownership structure on corporate R\&D strategy. Academy of Management Journal, 34(1): 20-214.

BEN-ZION, U. (1984). The R\&D and investment decision and its relationship to the firm s market value: Some preliminary results. In Z. Griliches (Ed.), R\&D, Patents, and Productivity. Chicago, IL: University of Chicago Press, $134-162$.

BERMAN, S.L.; WICKS, A.C.; KOTHA, S.; JONES, M.T. (1999). Does stakeholder orientation matter? The relationship between stakeholder management models and firm financial performance. Academy of Management Journal, 42(5): 488506. http://dx.doi.org/10.2307/256972

BOUQUET, C.; DEUTSCH, Y. (2008). The Impact of corporate social performance on a firm's multinationality. Journal of Business Ethics, 80: 755-769. http://dx.doi.org/10.1007/s10551-007-9467-4

BRAMMER, S.; PAVELIN, S. (2004). Building a good reputation. European Management Journal, 22(6): 704-713. http://dx.doi.org/10.1016/j.emj.2004.09.033

BRAMMER, S.; PAVELIN, S. (2006). Corporate reputation and social performance: The importance of fit. Journal of Management Studies, 43(3): 435-455. http://dx.doi.org/10.1111/j.1467-6486.2006.00597.x

BRANCO, M.C.; RODRIGUES, L.L. (2006). Corporate social responsibility and resource-based perspectives. Journal of Business Ethics, 69: 111-132. http://dx.doi.org/10.1007/s10551-006-9071-z

CARROLL, G.; HANNAN, M.T. (1989). Density delay in the evolution of organizational populations: a model and five empirical tests. Administrative Science Quarterly, 34(3): 411-430. http://dx.doi.org/10.2307/2393151

CARTER, S.M.; RUEFLI, T.W. (2006). Intra-industry reputation dynamics under a resource-based framework: Assessing the durability factor. Corporate Reputation Review, 9(1): 43-57. http://dx.doi.org/10.1057/palgrave.crr.1550006

CHUN, R. (2006). Innovation and reputation: An ethical character perspective. Innovation and Reputation Journal, 15(1): 63-73. 
CLARK, B.; GRILICHES, Z. (1984). Productivity and R\&D at the firm level in French manufacturing. In: Z. Griliches (Ed.), R\&D, patents, and productivity. Chicago: University of Chicago Press, 393-416.

CLARKSON M. (1995). A stakeholder framework for analyzing and evaluating corporate social performance. Academy of Management Review, 20: 92-117.

COLLIS, D.J.; MONTGOMERY, C.A. (1995). Competing on resources. Harvard Business Review, July-August, 118-128.

DAVIES, G.; MILES, L. (1998). Reputation management: Theory versus practice. Corporate Reputation Review, 2(1): 16-27. http://dx.doi.org/10.1057/palgrave.crr.1540064

DIMAGGIO, P.J.; POWELL, W.W. (1983). The iron cage revisited: Institutional isomorphism and collective rationality in organizational fields. American Sociological Review, 48: 147-160. http://dx.doi.org/10.2307/2095101

DIMAGGIO, P.J.; POWELL, W.W. (1991). The new institutionalism in organizational analysis. Chicago: University of Chicago Press.

DOH, J.P.; HOWTON, S.D.; HOWTON, S.W.; SIEGEL, D.S. (2009). Does the market respond to endorsement of social responsibility? The role of institutions, information and legitimacy. Journal of Management, 36(6): 1461-1485. http://dx.doi.org/10.1177/0149206309337896

DOWLING, G.R. (2004). Corporate reputation: Strategies for developing the corporate brand. London: Kogan Page.

DYER, J.H.; CHU, W. (2003). The role of trustworthiness in reducing transaction costs and improving performance: Empirical evidence from the United States, Japan, and Korea. Organization Science, 14(1): 57-68. http://dx.doi.org/10.1287/orsc.14.1.57.12806

FELDMAN, M.S.; MARCH, J.G. (1981). Information in organizations as signal and symbol. Administrative Science Quarterly, 26: 171-186. http://dx.doi.org/10.2307/2392467

FOMBRUN, C. (1996). Reputation: Realizing value from the corporate image. Harvard, MA: Harvard Business School Press. 
FOMBRUN, C.J.; SHANLEY, M. (1990). What $s$ in a name? Reputation building and corporate strategy. Academy of Management Journal, 33: 233-258. http://dx.doi.org/10.2307/256324

GALASKIEWICZ, J. (1991). Making corporate actors accountable: Institutionbuilding in Minneapolis-St. Paul. In W. W. Powell \& P. J. DiMaggio (Eds.), The new institutionalism in organizational analysis: 293-310. Chicago: University of Chicago Press.

GODFREY, P.C. (2005). The relationship between corporate philanthropy and shareholder wealth: A risk management perspective. Academy of Management Review 30: 777-798. http://dx.doi.org/10.5465/AMR.2005.18378878

GOFFMAN, E. (1969). Strategic interaction. Philadelphia: University of Pennsylvania Press.

GRANT, R.M. (1991). The resource-based theory of competitive advantage: Implications for strategy formulation. California Management Review, Spring: 114-135.

GRILICHES, Z. (1979). Issues in assessing the contribution of R\&D to productivity growth. Bell Journal of Economics, 10(1): 92-116. http://dx.doi.org/10.2307/3003321

GRILICHES, Z. (1998). R\&D and productivity: The Econometric evidence, national bureau of economic research for the university of Chicago Press. Chicago, IL: University of Chicago Press.

GUERARD, J.B.; BEAN, JR., A.S.; ANDREWS, S. (1987). R\&D management and corporate financial policy. Management Science, 33(11): 1419-1427. http://dx.doi.org/10.1287/mnsc.33.11.1419

GUERARD, J.B.; STONE, B.K.; ANDREWS, S. (1988). Corporate R\&D expenditures, innovation, and competition in an international economy. In R. Shrieves (Ed.), Competition in the international economy (pp. 215-250). Cambridge: Cambridge University Press.

HALL, B.H. (1999). Innovation and market value. National Bureau of Economic Research Working Paper, 6984. 
HALL, R. (1993). A framework linking intangible resources and capabilities to sustainable competitive advantage. Strategic Management Journal, 14(8): 607618. http://dx.doi.org/10.1002/smj.4250140804

HILLMAN, A.J.; KEIM, G.D. (2001). Shareholder value, stakeholder management, and social issues: What's the bottom line? Strategic Management Journal, 22: 125-139. http://dx.doi.org/10.1002/1097-0266(200101)22:2<125::AID-SMJ150>3.0.CO;2-H

HITT, M.A.; HOSKISSON, R.E.; KIM, H. (1997). International diversification: Effects on innovation and firm performance in product-diversified firms. Academy of Management Journal, 40(4): 767-798. http://dx.doi.org/10.2307/256948

HULL, C.E.; ROTHENBERG, S. (2008). Firm performance: The interactions of corporate social performance with innovation and industry differentiation. Strategic Management Journal, 29: 781-789. http://dx.doi.org/10.1002/smj.675

ITAMI, H. (1987). Mobilizing invisible assets. Cambridge, MA: Harvard University Press.

JONES, T.M. (1995). Instrumental stakeholder theory: A Synthesis of ethics and economics. Academy of Management Review, 20: 404-437.

KEH, H.T.; XIE, Y. (2008). Corporate reputation and customer behavioural intentions: The roles of trust, identification and commitment. Industrial Marketing Management, 38(7): 732-742. http://dx.doi.org/10.1016/j.indmarman.2008.02.005

LICHTENBERG, F.; SIEGEL, D.S. (1991). The impact of R\&D investment on productivity: New evidence using linked R\&D-LRD data. Economic Inquiry, 29: 203-228. http://dx.doi.org/10.1111/j.1465-7295.1991.tb01267.x

MARGOLIS, J.D.; ELFENBEIN, H.A.; WALSH, J.P. (2007). Does it pay to be good? A meta-analysis and redirection of research on the relationship between corporate social and financial performance. Academy of Management Meetings, Philadelphia, PA, August.

MCWILLIAMS, A.; SIEGEL D. (2000). Corporate social responsibility and financial performance: Correlation or misspecification? Strategic Management Journal, 21: 603-609. http://dx.doi.org/10.1002/(SICI)1097-0266(200005)21:5<603::AID-SMJ101>3.0.CO;2-3

MCWILLIAMS, A.; SIEGEL, D.S.; WRIGHT, P.M. (2006). Guest editors introduction, corporate social responsibility: Strategic implications. Journal of Management Studies, 43(1): 1-18. http://dx.doi.org/10.1111/j.1467-6486.2006.00580.x 
MEYER, J.W.; SCOTT, W.R. (1983). Organizational environments: Ritual and rationality. Beverly Hills, CA: Sage.

OLIVER, C. (1991). Strategic responses to institutional processes. Academy of Management Review, 16: 145-179.

OLIVER, C. (1997). Sustainable competitive advantage: Combining institutional and resource based views. Strategic Management Journal, 18(9):697-713. http://dx.doi.org/10.1002/(SICI)1097-0266(199710)18:9<697::AID-SMJ909>3.0.CO;2-C

ORLITZKY, M.; SCHMIDT, F.L.; RYNES, S.L. (2003). Corporate social and financial performance: A meta-analysis. Organization Studies, 24(3): 403-441. http://dx.doi.org/10.1177/0170840603024003910

PADGETT, R.C.; GALÁN, J.I. (2010). The effect of R\&D intensity on corporate social responsibility. Journal of Business Ethics, 93: 407-418. http://dx.doi.org/10.1007/s10551-009-0230-x

PETERAF, M.A. (1993). The cornerstones of competitive advantage: A resourcebased view. Strategic Management Journal, 14(3): 179-191. http://dx.doi.org/10.1002/smj.4250140303

PETERAF, M.A.; BARNEY, J. (2003). Unraveling the resource-based tangle. Journal of Managerial and Decision Economics, 24: 309-323. http://dx.doi.org/10.1002/mde.1126

POLONSKY, M.J., SUCHARD, H.T.; SCOTT, D. (1997). A stakeholder approach to interacting with the external environment. Australia and New Zealand Marketing Educators Conference Proceedings, 1: 495-508.

PORTER, M.E.; KRAMER, M. R. (2006). The link between competitive advantage and corporate social responsibility. Harvard Business Review, online version.

QUAZI, A.; O BRIEN, D. (2000). An empirical test of a cross-national model of corporate social responsibility. Journal of Business Ethics, 25: 33-51. http://dx.doi.org/10.1023/A:1006305111122

QUEVEDO-PUENTE, E.; FUENTE-SABATÉ, J.M.; DELGADO-GARCÍA, J.B. (2007). Corporate social performance and corporate reputation: Two interwoven perspectives. Corporate Reputation Review, 10(1): 60-72. http://dx.doi.org/10.1057/palgrave.crr.1550038 
RAO, H. (1994). The social construction of reputation: Certification contest, legitimating, and survival of organizations in the American automobile industry: 1895-1912. Strategic Management Journal, 15: 29-44. http://dx.doi.org/10.1002/smj.4250150904

ROBERTS, P.W.; DOWLING, G.R. (2002). Corporate reputation and sustained superior financial performance. Strategic Management Journal, 23: 1077-1093. http://dx.doi.org/10.1002/smj.274

RUSSO, M.V; FOUTS, P.A. (1997). A resource based perspective on corporate environmental performance and profitability. Academy of Management Journal, 40(3): 534-559. http://dx.doi.org/10.2307/257052

SABATE, J.M.; PUENTE, E. (2003). Empirical analysis of the relationship between corporate reputation and financial performance: A survey of the literature. Corporate Reputation Review, 6: 161-177. http://dx.doi.org/10.1057/palgrave.crr.1540197

SCHWARTZ, P.; GIBB, B. (1999). When good companies do bad things: Responsibility and risk in an age of globalization. New York: Wiley.

SCOTT, W.R. (1987). The adolescence of institutional theory. Administrative Science Quarterly, 32(4): 493-511. http://dx.doi.org/10.2307/2392880

SCOTT, W.R. (1995). Institutions and Organizations. Sage, Thousand Oaks, CA.

SURROCA, J.; TRIBÓ, J.A.; WADDOCK, S. (2009). Corporate responsibility and financial performance: the role of intangible resource. Strategic Management Journal, 31(5): 736-767.

SZWAJKOWSKI, E.; FIGLEWICZ, R. (1999). Evaluating corporate performance: A comparison of the Fortune reputation survey and the Socrates social rating database. Journal of Managerial Issues, 11(2): 137-154.

TOLBERT, P.S.; ZUCKER, L.G. (1983). Institutional sources of change in the formal structure of organizations: The diffusion of civil service reform, 1880-1935. Administrative Science Quarterly, 28: 22-39. http://dx.doi.org/10.2307/2392383

TURBAN, D.B.; GREENING, D.W. (1997). Corporate social performance and organizational attractiveness to prospective employees. Academy of Management Journal, 40: 658-672. http://dx.doi.org/10.2307/257057 
WAGNER, M. (2010). Corporate social performance and innovation with high social benefits: A quantitative analysis. Journal of Business Ethics, 94(4): 581-594. http://dx.doi.org/10.1007/s10551-009-0339-y

WEIGELT, K.; CAMERER, C. (1988). Reputation and corporate strategy: A recent theory and applications. Strategic Management Journal, 9: 443-454. http://dx.doi.org/10.1002/smj.4250090505

WERNERFELT, B. (1984). A resource-based view of the firm. Strategic Management Journal, 5(2): 171-180. http://dx.doi.org/10.1002/smj.4250050207

WOOD, D.J. (2010). Measuring corporate social performance review. International Journal of Management Reviews, 12(1): 50-84. http://dx.doi.org/10.1111/j.14682370.2009.00274.x

ZUKIN, S.; DIMAGGIO, P. (1990). Structures of capital: The social organization of the economy. New York: Cambridge University Press.

Intangible Capital, 2012 (www.intangiblecapital.org)

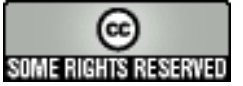

\footnotetext{
Article's contents are provided on a Attribution-Non Commercial 3.0 Creative commons license. Readers are allowed to copy, distribute and communicate article's contents, provided the author's and Intangible Capital journal's names are included. It must not be used for commercial purposes. To see the complete licence contents, please visit http://creativecommons.org/licenses/by-nc/3.0/es/
} 